\title{
Antigenic and biological comparisons of bovine coronaviruses derived from neonatal calf diarrhea and winter dysentery of adult cattle
}

\author{
Brief Report \\ H. Tsunemitsu and L. J.Saif \\ Food Animal Health Research Program, Ohio Agricultural Research and Development Center, \\ The Ohio State University, Wooster, Ohio, U.S.A.
}

Accepted February 24, 1995

Summary. The antigenic and biological properties of 6 strains of bovine coronavirus (BCV) derived from neonatal calf diarrhea (CD) and 8 strains of $\mathrm{BCV}$ from winter dysentery (WD) of adult cattle, propagated in HRT-18 cells, were compared to determine if $C D$ and WD strains belong to distinct serotypes or subtypes of $\mathrm{BCV}$. All strains hemagglutinated both mouse and chicken erythrocytes at $4^{\circ} \mathrm{C}$, but the ratios of hemagglutination titers with mouse erythrocytes compared to chicken erythrocytes showed diversity for both CD and WD strains. Some CD and WD strains did not hemagglutinate chicken erythrocytes at $37^{\circ} \mathrm{C}$ and showed receptordestroying enzyme activity against chicken erythrocytes. Hyperimmune antisera were produced in guinea pigs against 3 and 7 strains of BCV from $C D$ and WD, respectively. No significant differences in antibody titers against these strains were observed by indirect immunofluorescence tests. However, in virus neutralization tests, antisera to $1 \mathrm{CD}$ and $2 \mathrm{WD}$ strains had 16 -fold or lower antibody titers against $3 \mathrm{WD}$ and $1 \mathrm{CD}$ strains than against the homologous strains, and this variation reflected low antigenic relatedness values $(R=13-25 \%)$, suggesting the presence of different subtypes among $\mathrm{BCV}$. In hemagglutination inhibition tests, some one-way antigenic variations among strains were also observed. These results suggest that some antigenic and biological diversity exists among BCV strains, but these variations were unrelated to the clinical source of the strains; i.e. CD or WD.

Bovine coronavirus (BCV) is a primary cause of neonatal calf diarrhea (CD) worldwide $[4,13]$. Bovine coronavirus is also associated with acute diarrhea in adult cattle during the winter season referred to as winter dysentery (WD) $[4,17,18$, $24,26]$. Besides infecting the small and large intestines of calves, BCV also possesses a tissue tropism for the upper respiratory tract [15]. 
Bovine coronavirus has four major structural proteins: the nucleocapsid protein $(\mathrm{N})$, the transmembrane protein $(\mathrm{M})$, the spike protein $(\mathrm{S})$ and the hemagglutininesterase protein (HE) [21]. The $\mathrm{S}$ and HE proteins form fringes of longer and shorter surface projections, respectively [4]. Both proteins can cause hemagglutination (HA) and contain neutralizing epitopes [7, 20]. The HE protein also possesses receptor-destroying enzyme (RDE) which inactivates cellular receptors for $\mathrm{BCV}$ by hydrolyzing an ester bond to release acetate from $\mathrm{C}-9$ of sialic acid $[4,27]$.

Because the primary isolation of $\mathrm{BCV}$ remains difficult, there have been only a few investigations on antigenic comparisons of BCV strains $[6,8,11,14]$. Specifically, whether antigenic or biological differences exist between strains derived from CD and WD remains obscure [2]. The purpose of this study was to isolate BCV strains from feces derived from CD and WD in human rectal tumor (HRT-18) cells and to compare the antigenic and biological properties of these strains.

The Mebus strain of CD BCV [13] was provided by Dr. K. W. Theil of our institute (originally supplied by Dr. D. A. Brian, The University of Tennessee, Knoxville, Tennessee, U.S.A.), and had been passaged at least 40 times in fetal bovine kidney (FBK) cells and 20 times in embryonic bovine kidney (BEK) cells. It was propagated 8 times in bovine turbinate (BT) cells, 6 times in bovine kidney (MDBK) cells and 3 times in HRT-18 cells in our laboratory. The 216XF strain isolated from a newborn beef calf with diarrhea in Japan was propagated 10 times in HRT-18 cells [25]. The DBA strain of WD BCV was propagated 8 times in HRT-18 cells in our laboratory as previously described [2]. The SD strain of WD BCV was kindly supplied by Dr. D. A. Benfield, The South Dakota University, Brookings, South Dakota, U.S.A., and was propagated 8 times in HRT-18 cells. Six WD isolates of $\mathrm{BCV}$ designated as the TS, CN, BE, BM, AW and BW strains, were isolated from fecal samples of gnotobiotic calves which had been inoculated with fecal filtrates from affected adult dairy cows from 6 herds in the U.S.A. including Ohio ( 3 herds) and Wisconsin ( 3 herds), which were experiencing typical outbreaks of WD during the winters of 1987 to 1993. Three CD isolates of BCV designated as the DB2, OHC and SDC strains, were isolated from fecal samples of neonatal calves with acute diarrhea from 3 herds in the U.S.A. including Ohio ( 2 herds) and South Dakota (1 herd). A fourth CD isolate (JAZ) was isolated from a neonatal calf with acute diarrhea in Hokkaido, Japan. Virus isolation on HRT-18 cells was done as previously described $[2,25]$ except that $10 \mu \mathrm{g} / \mathrm{ml}$ of pancreatin (Gibco Laboratories, Grand Island, N.Y.) was added to the maintenance medium. Confirmation of the isolates as $\mathrm{BCV}$ was done by using immune electron microscopy [16] and immunofluorescence (IF) [2] with hyperimmune antiserum prepared against the Mebus strain of CD BCV. The isolated viruses, which were passaged a total of 5 to 10 times in HRT-18 cells were plaque-purified at least once before use.

Hyperimmune antisera were prepared in guinea pigs against $3 \mathrm{CD}$ strains (Mebus, DB2, 216XF) and 7 WD strains (SD, BM, CN, AW, DBA, TS, BE) of $\mathrm{BCV}$ that had been propagated in HRT-18 cells for 6 to 11 passages and then purified on sucrose gradients [5]. These antisera were used for serological tests.

Hemagglutination (HA) tests were conducted by the microtiter method [19]. Bovine coronavirus strains were purified from infected-cell culture supernatants, 
which were concentrated approximately 100 -to 200 -fold. Serial 2-fold dilutions of $\mathrm{BCV}$ were prepared in $0.05 \mathrm{ml}$ of veronal buffered saline containing $0.1 \%$ bovine serum albumin and $0.001 \%$ gelatin and mixed with $0.05 \mathrm{ml}$ of 0.8 and $0.4 \%$ suspensions of mouse and pooled adult chicken erythrocytes, respectively, in the same buffer. The mixtures were then incubated for 1 h at either 4 or $37^{\circ} \mathrm{C}$ and the HA titers were determined. The plates incubated at $4{ }^{\circ} \mathrm{C}$ were moved to $37^{\circ} \mathrm{C}$ for $2 \mathrm{~h}$ to measure inactivation of receptors reflected by the disaggregation of the $\mathrm{BCV}$-erythrocyte complexes mediated by the receptor destroying enzyme (RDE) activity [22].

Antigenic comparisons of $\mathrm{BCV}$ strains were done by indirect IF, virus neutralization (VN) and HA inhibition (HI) tests. The indirect IF tests were performed as previously described [8]. Virus titration and VN tests were conducted with HRT-18 cells in microplates as previously described [25]. Virus infectivity titers were expressed as median tissue culture infective doses $\left(\mathrm{TCID}_{50}\right) / \mathrm{ml}$. The VN antibody titers were expressed as the reciprocal of the highest serum dilution that completely inhibited cytopathic effects (CPE). The antigenic relatedness $(R)$ between the strains was calculated using the formula $[1,8]$ :

$$
R=100 \sqrt{r 1 \times r 2} \%
$$

in which $r 1$ is heterologous titer (strain 2)/homologous titer (strain 1), and $r 2$ is heterologous titer (strain 1)/homologous titer (strain 2). The HI test was done using standard techniques with mouse erythrocytes [19] and sera treated with kaolin and mouse erythrocytes. The antibody titers were expressed as the reciprocal of the highest serum dilutions producing complete HI.

Cytopathic effects were evident in HRT-18 cells inoculated with each of the strains of BCV. Cytopathic effects were characterized by enlarged, rounded, and densely granular cells that occurred in clusters at 2 to 3 postinoculation days [2], and no differences were observed in CPE among these strains. Syncytia were also clearly observed in HRT-18 cells at 2 days after inoculation with these strains following staining with fluorescein isothiocyanate-conjugated anti-BCV serum. Infectivity titers of $\mathrm{BCV}$ reached $10^{7.0}$ to $10^{8.7} \mathrm{TCID}_{50} / \mathrm{ml}$ at the 5 th to 10 th passages on $\mathrm{HRT}-18$ cells.

The HA and RDE titers of purified BCV strains are summarized in Table 1. All strains agglutinated mouse erythrocytes and no differences were observed in HA titers against mouse erythrocytes at $4^{\circ}$ and $37^{\circ} \mathrm{C}$. All strains also agglutinated chicken erythrocytes at $4^{\circ} \mathrm{C}$, but the HA titers varied among the $\mathrm{BCV}$ strains. This diversity was reflected in variations of the ratios of HA titer with mouse erythrocytes to $\mathrm{HA}$ titer with chicken erythrocytes (M/C HA titer ratio) at $4{ }^{\circ} \mathrm{C}$. However there was no relation between $\mathrm{M} / \mathrm{C}$ HA titer ratio and the clinical source (CD or WD) of the strains. At $37^{\circ} \mathrm{C}$, the Mebus and DB2 strains of $\mathrm{CD} \mathrm{BCV}$ and the DBA and SD strains of WD BCV agglutinated chicken erythrocytes with the same HA titers as at $4^{\circ} \mathrm{C}$. However, the other strains of $\mathrm{BCV}$ did not agglutinate chicken erythrocytes at $37^{\circ} \mathrm{C}$, and showed RDE activity against chicken erythrocytes. Receptor-destroying enzyme activity with mouse erythrocytes was not 
Table 1. Hemagglutination (HA) and receptor-destroying enzyme (RDE) activities of purified BCV strains

\begin{tabular}{|c|c|c|c|c|c|c|c|}
\hline \multirow{3}{*}{$\begin{array}{l}\mathrm{BCV} \\
\text { strain } \\
\text { (Derivation }{ }^{\mathrm{C}} \text { ) }\end{array}$} & \multicolumn{5}{|c|}{ HA titer ${ }^{a}$} & & \\
\hline & \multicolumn{3}{|l|}{$4^{\circ} \mathrm{C}$} & \multicolumn{2}{|l|}{$37^{\circ} \mathrm{C}$} & \multicolumn{2}{|c|}{ RDE titer ${ }^{b}$} \\
\hline & Mouse & Chicken & $\mathrm{M} / \mathrm{C}^{\mathrm{d}}$ & Mouse & Chicken & $\overline{\text { Mouse }}$ & Chicken \\
\hline $\operatorname{Mebus}(C D)$ & 102400 & 25600 & 4 & 102400 & 25600 & $<12.5$ & $<12.5$ \\
\hline $\mathrm{DB} 2(\mathrm{CD})$ & 102400 & 12800 & 8 & 102400 & 12800 & $<12.5$ & $<12.5$ \\
\hline DBA(WD) & 51200 & 3200 & 16 & 51200 & 3200 & $<12.5$ & $<12.5$ \\
\hline $\mathrm{SD}(\mathrm{WD})$ & 51200 & 3200 & 16 & 51200 & 3200 & $<12.5$ & $<12.5$ \\
\hline $216 \times F(C D)$ & 25600 & 1600 & 16 & 25600 & $<12.5$ & $<12.5$ & $\geq 1600$ \\
\hline $\mathrm{CN}(\mathrm{WD})$ & 6400 & 1600 & 4 & 6400 & $<12.5$ & $<12.5$ & $\geq 1600$ \\
\hline BE(WD) & 51200 & 1600 & 32 & 51200 & $<12.5$ & $<12.5$ & $\geq 1600$ \\
\hline $\mathrm{AW}(\mathrm{WD})$ & 51200 & 1600 & 32 & 51200 & $<12.5$ & $<12.5$ & $\geq 1600$ \\
\hline $\mathrm{OHC}(\mathrm{CD})$ & 51200 & 200 & 256 & 51200 & $<12.5$ & $<12.5$ & $\geq 200$ \\
\hline $\mathrm{SDC}(\mathrm{CD})$ & 51200 & 200 & 256 & 51200 & $<12.5$ & $<12.5$ & $\geq 200$ \\
\hline $\mathrm{JAZ}(\mathrm{CD})$ & 51200 & 100 & 512 & 51200 & $<12.5$ & $<12.5$ & $\geq 100$ \\
\hline $\mathrm{TS}(\mathrm{WD})$ & 51200 & 100 & 512 & 51200 & $<12.5$ & $<12.5$ & $\geq 100$ \\
\hline $\mathrm{BM}(\mathrm{WD})$ & 25600 & 100 & 256 & 25600 & $<12.5$ & $<12.5$ & $\geq 100$ \\
\hline $\mathrm{BW}(\mathrm{WD})$ & 25600 & 100 & 256 & 25600 & $<12.5$ & $<12.5$ & $\geq 100$ \\
\hline
\end{tabular}

${ }^{\text {a }}$ Expressed as the reciprocal of the highest dilution of virus showing complete HA of 0.4 and $0.2 \%$ suspensions of mouse and chicken erythrocytes, respectively, after $1 \mathrm{~h}$ incubation at $4{ }^{\circ} \mathrm{C}$ or $37^{\circ} \mathrm{C}$

${ }^{b}$ Expressed as the reciprocal of the highest dilution of virus causing complete disappearance of HA patterns at $4{ }^{\circ} \mathrm{C}$ after $2 \mathrm{~h}$ incubation at $37^{\circ} \mathrm{C}$

${ }^{\circ} C D$ Calf diarrhea, $W D$ winter dysentery of adult cattle

${ }^{\mathrm{d}} \mathrm{M} / \mathrm{C}$ Ratio of HA titer with mouse erythrocytes to HA titer with chicken erythrocytes

detected for any strain of $\mathrm{BCV}$. According to these results, BCV strains were classified into 3 groups. The first group (CD isolates, Mebus, DB2; and WD isolates, DBA, SD) showed low M/C HA titer ratios $(\leq 16)$, no differences in HA titers against chicken erythrocytes at 4 and $37^{\circ} \mathrm{C}$ and no $\mathrm{RDE}$ activity against chicken erythrocytes. The second group (CD isolate, 216XF; and WD isolates, $\mathrm{CN}$, $\mathrm{BE}, \mathrm{AW}$ )showed low M/CHA titer ratios ( $\leq 32)$, no HA against chicken erythrocytes at $37^{\circ} \mathrm{C}$ and $\mathrm{RDE}$ activity with chicken erythrocytes. The third group (CD isolates, OHC, SDC, JAZ; and WD isolates, TS, BM, BW) showed high M/C HA titer ratios $(\geq 256)$, no HA against chicken erythrocytes at $37^{\circ} \mathrm{C}$ and $\mathrm{RDE}$ activity with chicken erythrocytes. These variations in $\mathrm{HA}$ and $\mathrm{RDE}$ activities were unrelated to the clinical source of the isolates (CD or WD).

In indirect IF tests, all of the antisera reacted to each virus strain with high titer (102 400 to 409600 ), and each antiserum showed no significant differences in reactivity with the homologous and heterologous strains (not greater than twofold differences).

The results of VN tests are shown in Table 2 . All of the antisera neutralized the heterologous strains, showing that the strains were closely related antigenically. 
$\mathrm{BCV}$ antigenic and biological comparisons

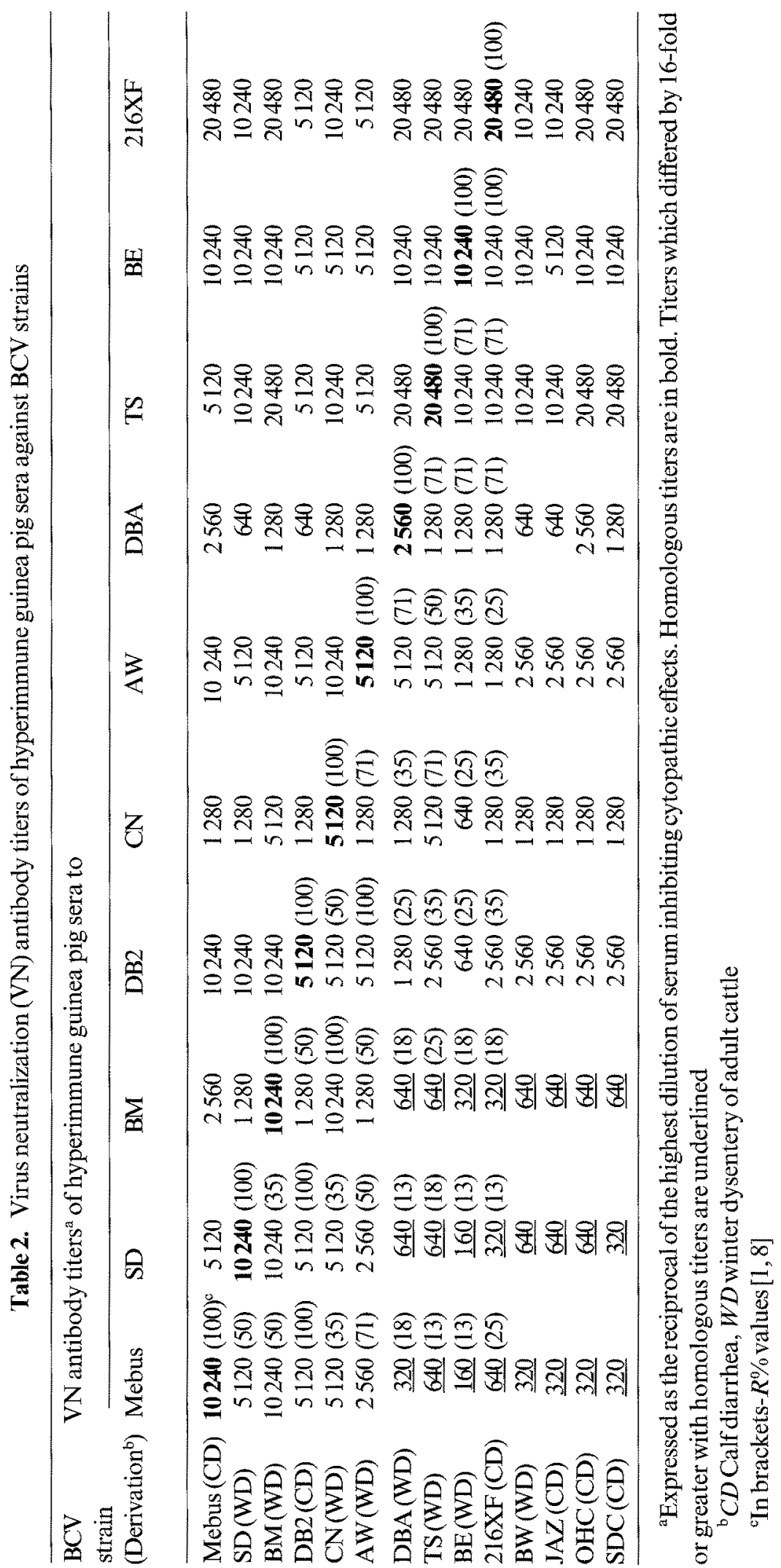


However, antisera to the Mebus CD, and SD and BM WD strains showed 16-fold or lower VN antibody titers against the DBA, TS, BE and BW WD strains and the 216XF, JAZ, OHC and SDC CD strains than against the homologous strains. These differences were reflected in the $R \%$ values: the Mebus, SD and BM strains generated $R \%$ values of 13 to 25 against the DBA, TS, BE and $216 \mathrm{XF}$ strains.

The HI antibody titers are shown in Table 3. All of the strains showed crossreactivity, but differences in antibody titers were observed. The DB2 strain of CD BCV and the SD strain of WD BCV were closely related in the HI tests, and antisera to these strains distinguished most other strains with 16 -fold or greater differences in the $\mathrm{HI}$ antibody titers.

Bovine coronavirus causes neonatal CD [13] and is also associated with WD of adult cattle [17]. Based on epidemiological data, these disease syndromes often occur as separate and distinct outbreaks in herds $[4,12,17]$; hence antigenic or biological differences between CD and WD BCV might be expected. Calf diarrhea BCV isolates belong to a single serotype $[4,15,25]$, but minor antigenic and biological variations among them have been revealed in limited studies $[6,8,11,14,23]$. In this study, we compared the antigenic and biological diversity of a variety of WD and CD BCV isolates.

Storz et al. [23] reported that variations in the ratios of HA titers with mouse erythrocytes to those with chicken erythrocytes (M/C HA titer ratio in this report)

Table 3. Hemagglutination inhibition(HI) antibody titers of hyperimmune guinea pig sera against $\mathrm{BCV}$ strains

\begin{tabular}{|c|c|c|c|c|c|c|c|c|c|c|}
\hline \multirow{2}{*}{$\begin{array}{l}\mathrm{BCV} \\
\text { strain } \\
\text { (Derivation }^{\mathrm{b}} \text { ) }\end{array}$} & \multicolumn{10}{|c|}{$\mathrm{HI}$ antibody titers ${ }^{\mathrm{a}}$ of hyperimmune guinea pig sera to } \\
\hline & DB2 & $\mathrm{SD}$ & Mebus & $216 \mathrm{XF}$ & DBA & $\mathrm{CN}$ & BM & AW & TS & $\mathrm{BE}$ \\
\hline $\mathrm{DB} 2(\mathrm{CD})$ & $\geq 20480$ & $\geq 20480$ & 320 & 1280 & 160 & 320 & 320 & 320 & $\geq 20480$ & 5120 \\
\hline $\mathrm{SD}(\mathrm{WD})$ & $\geq 20480$ & $\geq 20480$ & 80 & 2560 & 160 & 320 & 320 & 320 & 20480 & 5120 \\
\hline Mebus(CD) & 2560 & $\underline{320}$ & 160 & 2560 & 640 & 160 & 320 & 320 & 5120 & 1280 \\
\hline $216 \mathrm{XF}(\mathrm{CD})$ & 1280 & $\underline{80}$ & 160 & 2560 & 80 & 640 & 160 & 320 & 10240 & 2560 \\
\hline DBA(WD) & 1280 & $1 \overline{60}$ & 160 & 1280 & 160 & 640 & 320 & 320 & $\geq 20480$ & 1280 \\
\hline $\mathrm{CN}(\mathrm{WD})$ & $\underline{640}$ & $\underline{80}$ & 40 & 640 & 40 & 640 & 160 & 160 & 10240 & 640 \\
\hline BM(WD) & $\underline{640}$ & $\underline{80}$ & 40 & 1280 & 80 & 160 & 160 & 80 & 5120 & 1280 \\
\hline AW (WD) & $\underline{1280}$ & $\underline{80}$ & 40 & 2560 & 80 & 1280 & 160 & 640 & 20480 & 5120 \\
\hline TS(WD) & 5120 & $\underline{160}$ & 80 & 1280 & 160 & 1280 & 320 & 640 & 20480 & 5120 \\
\hline $\mathrm{BE}(\mathrm{WD})$ & 1280 & $\underline{160}$ & 160 & 1280 & 160 & 640 & 80 & 80 & 5120 & 5120 \\
\hline $\mathrm{BW}(\mathrm{WD})$ & $\underline{640}$ & 80 & 40 & 1280 & 40 & 160 & 40 & 160 & 10240 & 2560 \\
\hline $\mathrm{JAZ}(\mathrm{CD})$ & $\underline{1280}$ & 160 & 40 & 1280 & 40 & 320 & 40 & 160 & 10240 & 5120 \\
\hline $\mathrm{OHC}(\mathrm{CD})$ & 1280 & 160 & 80 & 2560 & 80 & 320 & 80 & 320 & 5120 & 2560 \\
\hline $\mathrm{SDC}(\mathrm{CD})$ & 1280 & 160 & 40 & 2560 & 40 & 320 & 80 & 160 & 5120 & 2560 \\
\hline
\end{tabular}

${ }^{a}$ Expressed as the reciprocal of the highest dilution of serum inhibiting HA activity. Homologous titers are in bold. Titers which differed by 16 -fold or greater with homologous titers are underlined

${ }^{\mathrm{b}} \mathrm{CD}$ Calf diarrhea, $W D$ winter dysentery of adult cattle 
were observed among CD BCV strains. The L9 strain of CD BCV at the high cell culture passage level (the 78th passage) showed a low M/C HA titer ratio (8) whereas the wild type CD BCV strains at low cell culture passage levels (the 3rd to 8th passages) showed high M/C HA titer ratios (128 to 256). In this study, the high cell culture-passaged Mebus strain of CD BCV (the 77th passage) showed a low M/C HA titer ratio (2), but some low cell culture-passaged CD strains (DB2, 216XF) and WD strains (CN, DBA, SD, BE, AW) of BCV (the 5th to 10th passages) also showed low $\mathrm{M} / \mathrm{C}$ ratios (4 to 32 ). The differences in HA titers against chicken erythrocytes at $4^{\circ}$ and $37^{\circ} \mathrm{C}$ showed good agreement with the RDE titers for chicken erythrocytes. This suggests that comparison of $\mathrm{HA}$ titers obtained at $4^{\circ}$ and $37^{\circ} \mathrm{C}$ may provide an alternative method for evaluting RDE activity. On the basis of HA and RDE patterns, BCV strains were classified into 3 groups. However, each group contained both $\mathrm{CD}$ and WD BCV and no relationship between each group and the clinical (CD or WD) or geographic origin of the strains was observed.

All strains of both CD and WD BCV examined in this study were related antigenically. Specially, each antiserum showed no significant difference between the homologous and heterologous strains in indirect IF antibody titers. However, some antigenic diversity among $\mathrm{BCV}$ strains was observed by $\mathrm{VN}$ and $\mathrm{HI}$ tests. In our previous report [2], hyperimmune antiserum prepared in a gnotobiotic calf to the Mebus strain of CD BCV had an 8- to 32-fold lower VN antibody titer against the DBA strain of WD BCV than against the homologous strain. In this study, guinea pig hyperimmune antiserum to the Mebus strain showed similar VN antibody titer differences between homologous and the DBA strains. In addition, this serum also distinguished three other strains of WD BCV and four strains of CD BCV from the homologous virus by 16-to 64-fold differences. Moreover, hyperimmune antisera to the SD and BM strains of WD BCV also distinguished the same strains which were distinguished by the anti-Mebus serum, form homologous strains by 16 - to 64 -fold differences in antibody titers in VN tests. Although these variations were recognized only in one-way reactions and all strains examined could be classified into a single serotype, the strains showing these variations might be further divided into 2 subtypes. The Mebus, SD and BM strains which belong to the same potential subtype could be distinguished from the DBA, TS, BE and 216XF strains, which constitute another possible subtype ( $R \%$ values of 13 to 25 ). The BW, JAZ, OHC and SDC strains also appeared to belong to the latter subtype. The DB2, CN and AW strains comprised an intermediate group that cross-reacted with both subtypes. Interestingly, antiserum to the Mebus strain of $\mathrm{BCV}$ which had been prepared in guinea pig in Japan showed only a 2 -fold lower VN antibody titer against the 216XF strain than against the homologous strain [25]. In the present study, antiserum to the Mebus strain prepared in the U.S.A. had 16 -fold VN antibody titer differences against the homologous and 216XF strains. The reason for this discrepancy is unknown, but differences in the passage level of the Mebus strain at the preparation of antiserum might affect the virus antigenicity [10]. Alternatively, contamination of cultures with other BCV might occur after import and propagation in Japan.

Bovine coronavirus strains examined in this study showed minor antigenic and biological variations, but this diversity was unrelated to the geographic origin or 
affected animal age groups (WD and CD) from which these strains were recovered. Based on preliminary data, gnotobiotic and colostrum-deprived calves inoculated orally and nasally with WD BCV shed BCV rectally and nasally and developed diarrhea, which was indistinguishable from disease symptoms in calves inoculated with CD BCV [9]. Also, a cow inoculated via a duodenal cannula with CD BCV developed diarrhea and shed BCV (H. Tsunemitsu et al. 1994' unpublished data). These results suggest that the differences in these disease syndromes (WD and CD) are not related to viral factors, but to host and environmental factors; e.g. the immunological status of animals, environmental temperatures, secondary or coinfections with other pathogens, etc. $[3,12,17]$. Further studies are in progress to compare the antigenicity of BCV strains using monoclonal antibodies and in vivo cross-protection tests.

\section{Acknowledgements}

The authors thank Z. R. El-Kanawati and A. G. Agnes for technical assistance. Salaries and research support were provided by State and Federal funds appropriated to the Ohio Agricultural Research and Development Center (OARDC), The Ohio State University. The material is based upon work supported by the USDA, Cooperative State Research Service, Competitive Grant No. 90-34116-5364. Approved as OARDC journal article No. 4-95.

\section{References}

1. Archetti I, Horsfall FL (1950) Persistent antigenic variation of influenza A viruses after incomplete neutralization in vivo with heterologous immune serum. J Exp Med 92: 441- 462

2. Benfield DA, Saif LJ (1990) Cell culture propagation of a coronavirus isolated from cows with winter dysentery. J Clin Microbiol 28: 1454-1457

3. Campbell SG, Cookingham CA (1978) The enigma of winter dysentery. Cornell Vet 68:423-441

4. Clark MA (1993) Bovine coronavirus. Br Vet J 149: 51-70

5. Crouch CF, Raybould TJG (1983) Comparison of different antigen preparations as substrates for use in passive hemagglutination and enzyme-linked immunosorbent assays for detection of antibody against bovine enteric coronavirus. J Clin Microbiol 18: 146-149

6. Dea S, Roy RS, Elazhary MASY (1982) Antigenic variations among calf diarrhea coronaviruses by immunodiffusion and counterimmuno-electrophoresis. Ann Rech Vet 13:351-356

7. Deregt D, Babiuk LA (1987) Monoclonal antibodies to bovine coronavirus: characteristics and topographical mapping of neutralizing epitopes on the E2 and E3 glycoproteins. Virology 161:410-420

8. El-Ghorr AA, Snodgrass DR, Scott FMM, Campbell I (1989) A serological comparison of bovine coronavirus strains. Arch Virol 104: 241-248

9. El-Kanawati ZR, Tsunemitsu H, Smith DR, Saif LJ (1994) Infection and cross-protection studies of winter dysentery and calf bovine coronavirus strains in gnotobiotic calves. In: Proceedings of the 75th Annual Meeting of the Conference of Research Workers in Animal Diseases, Chicago, Illinois, Abstract No 77, p 10

10. Hohdatsu T, Eiguchi Y, Tsuchimoto M, Ide S, Yamagishi H, Matsumoto M(1987) Antigenic variation of porcine transmissible gastroenteritis virus detected by monoclonal antibodies. Vet Microbiol 14: 115-124 
11. Hussain KA, Storz J, Kousoulas KG (1991) Comparison of bovine coronavirus (BCV) antigens: monoclonal antibodies to the spike protein distinguish between vaccine and wildtype strains. Virology $183442-445$

12. Jactel B, Espinasse J, Viso M, Valiergue H(1990) An epidemiological study of winter dysentery in fifteen herds in France. Vet Res Commun 14:367-379

13. Mebus CA, Stair EL, Rhodes MB, Twiehaus MF (1973) Neonatal calf diarrhea: propagation, attenuation, and characteristics of coronavirus-like agents. Am J Vet Res 34: 145-150

14. Michaud L, Dea S (1993) Characterization of monoclonal antibodies to bovine enteric coronavirus and antigenic variability among Quebec isolates. Arch Virol 131:455-465

15. Reynolds DJ, Debney TG, Hall GA, Thomas LH, Parsons KR (1985) Studies on the relationship between coronaviruses from the intestinal and respiratory tracts of calves. Arch Virol 85:71-83

16. Saif LJ, Bohl EH, Kohler EM, Hughes JH (1977) Immune electron microscopy of transmissible gastroenteritis virus and rotavirus (reovirus-like agent) of swine. Am J Vet Res 38: $13-20$

17. Saif LJ (1990) A review of evidence implicating bovine coronavirus in the ethiology of winter dysentery in cows: an enigma resolved? Cornell Vet 80: 303-311

18. Saif LJ, Brock KV, Redman DR, Kohler EM (1991) Winter dysentery in dairy herds: electron microscopic and serological evidence for an association with coronavirus infection. Vet Rec 128:447-449

19. Sato K, Inaba Y, Kurogi H, Takahashi E, Satado K, Omori T, Matsumoto M (1977) Hemagglutination by calf diarrhea coronavirus. Vet Microbiol 2: 83-87

20. Schultze B, Gross HJ, Brossmer R, Herrler G(1991) The S protein of bovine coronavirus is a hemagglutinin recognizing 9- $O$-acetylated sialic acid as a receptor determinant. J Virol 65:6232-6237

21. Spaan W, Cavanagh D, Horzinek MC (1988) Coronaviruses: structure and genome expression. J Gen Virol 69:2939-2956

22. Storz J, Herrler G, Snodgrass DR, Hussain KA, Zhang XM, Clark MA, Rott R (1991) Monoclonal antibodies differentiate between the haemagglutinating and the receptordestroying activities of bovine coronavirus. J Gen Virol 72: 2817-2820

23. Storz J, Zhang XM, Rott R (1992) Comparison of hemagglutinating, receptor-destroying, and acetylesterase activities of avirulent and virulent bovine coronavirus strains. Arch Virol 125: $193-204$

24. Takahashi E, Inaba Y, Sato K, Ito $Y$, Kurogi H, Akashi H, Satoda K, OmoriT (1980) Epizootic diarrhea of adult cattle associated with a coronavirus-like agent. Vet Microbiol 5: 151-154

25. Tsunemitsu H, Yonemichi H, Hirai T, Kudo T, Onoe S, Mori K, Shimizu M(1991) Isolation of bovine coronavirus from feces and nasal swabs of calves with diarrhea. $\mathbf{J}$ Vet Med Sci 53:433-437

26. Van Kruiningen HJ, Castellano VP, Torres A, Sharpee RL (1991) Serologic evidence of coronavirus infection in New York and New England dairy cattle with winter dysentery. J Vet Diagn Invest 3: 293-296

27. Vlasak R, Luytjes W, Spaan W, Palese P (1988) Human and bovine coronaviruses recognize sialic acid-containing receptors similar to those of influenza $C$ viruses. Proc Natl Acad Sci USA $85: 4526-4529$

Authors' address: Dr. L. J. Saif, Food Animal Health Research Program, Ohio Agricultural Research and Development Center, 1680 Madison Avenue, Wooster, OH 44691, U.S.A.

Received January 9, 1995 